\title{
Mitigasi Rantai Pasok Rumput Laut dengan Pendekatan House of Risk dan Fuzzy AHP di Kabupaten Maluku Tenggara
}

\author{
Asymmetric Information Mitigation on Seaweed Supply Chain Using House of Risk and Fuzzy AHP Approach \\ Wellem Anselmus Teniwut ${ }^{1 *}$, Kamilius Deleles Betaubun ${ }^{1}$, M. Marimin $^{2}$, Taufik Djatna ${ }^{2}$ \\ ${ }^{1}$ Program Studi Agribisnis Perikanan, Politeknik Perikanan Negeri Tual, Jl. Raya Langgur-Sathean Km. 7, Langgur, \\ Kabupaten Maluku Tenggara, 97611, Indonesia \\ 2Departemen Teknologi Industri Pertanian, Fakultas Teknologi Pertanian, Institut Pertanian Bogor, Jl. Lingkar \\ Akademik, Jawa Barat 16680, Indonesia \\ *Penulis korespondensi: Wellem Anselmus Teniwut, E-mail: wateniwut@polikant.ac.id
}

Tanggal submisi: 28 Agustus 2017; Tanggal penerimaan: 4 Maret 2020

\begin{abstract}
ABSTRAK
Rumput laut merupakan salah satu komoditas perikanan yang memiliki potensi ekonomi yang cukup besar. Provinsi Maluku khususnya Kabupaten Maluku Tenggara adalah salah satu produsen rumput laut terbesar di kawasan timur Indonesia, namun sejak 2012 produksi dan jumlah petani rumput laut mengalami penurunan yang cukup signifikan. Tujuan dari penelitian ini adalah untuk melakukan mitigasi asimetris informasi rantai pasok rumput laut di wilayah ini.Penelitian ini menggunakan pendekatan House of Risk (HOR) untuk mengidentifikasi sumber utama risiko rantai pasok budidaya rumput laut yang krusial untuk segera diatasi dengan HOR 1 dan selanjutnya menggunakan pendekatan HOR 2 dan fuzzy AHP sebagai pendekatan komparasi untuk memilih alternatif terbaik untuk mitigasi asimetris informasi rantai pasok yang terjadi. Data dikumpulkan dengan kuesioner dan depth interview dengan para pakar yang dibagi menjadi tiga kategori praktisi, akademisi dan birokrat dengan jumlah masing-masing dua orang. Hasil dari studi ini menunjukkan bahwa di Kabupaten Maluku Tenggara terdapat 5 risiko yang menyumbang $70 \%$ dari seluruh risiko yang muncul. Selanjutnya, berdasarkan hasil ETD (Effectiveness to Difficulty)langkah yang dapat diambil untuk mengurangi risiko operasional rantai pasok rumput laut di wilayah ini adalah membangun komunitas petani rumput laut. Hal ini terkait dengan biaya yang dikeluarkan, kemudahan dan keuntungan dari adanya komunitas petani rumput laut.Selanjutnya aktor yang paling berperan adalah pemerintah daerah serta alternatif terbaik saat ini untuk mengurangi adanya asimetris informasi rantai pasok adalah dengan membangun pusat informasi rantai pasok.
\end{abstract}

Kata kunci: Asimetris informasi; mitigasi risiko; rumput laut; rantai pasok

\begin{abstract}
Seaweed is among fishery commodities with great potential economy prospect. Southeast Maluku District is one of the main producers in Eastern region of Indonesia. Despite the high production since 2012, the number of farmers and the product has declined due to inadequate supply chain coordination and information dissemination among members. Therefore, this study aimed to mitigate the assymetric information in the region using the house of risk (HOR) to identify the risks to be addressed, and also provide response on the source of supply chain risk. Furthermore, Analytic hierarchy process (AHP) with fuzzy approach was used to determine the major factor, and then choose the best alternative to mitigate asymmetric information in the supply chain. Results showed there were five factors that contributed $70 \%$ risks. The results also indicated that dependence on local distributor was a factor that had to be prioritized and addressed. In addition, to mitigate the operational risks, findings
\end{abstract}


showed it is necessary to establish seaweed farmers forum, which is the best approach based on the cost and effectiveness. This study also stated that local government of Southeast Maluku District was the main actor that helps to overcome the risks and asymmetric information problem. Therefore, the best alternative was to form an information center for seaweed cultivation, which will provide the knowledge of prices and potential buyer outside the region.

Keywords: Asymmetric information; risks mitigation; seaweed; supply chain

\section{PENDAHULUAN}

Aliran informasi yang tanpa distorsi dalam menghasilkan jaringan rantai pasok yang efektif menjadi sangat signifikan posisinya dalam lingkungan bisnis sekarang ini. Gunasekaran dkk. (2005) mengemukakan bahwa bisnis dengan jaringan kerja sama yang luas jika dibandingkan dengan bisnis model tradisional akan lebih memiliki peluang untuk dapat bersaing dan bertahan dalam persaingan. Dengan adanya kerja sama yang luas maka aliran informasi akan semakin lancar sehingga akan berdampak pada kemampuan setiap sektor bisnis yang ada untuk dapat selalu bersaing pada era dimana perpindahan informasi dan perubahan keinginan konsumen yang cukup cepat sekarang ini. Pembagian informasi dalam sebuah jaringan kerja sama rantai pasok maka setiap pihak akan dapat membuat keputusan yang lebih baik pada jumlah permintaan produk, alokasi sumber daya terkait dengan perencanaan dan biaya produksi yang mana kondisi ini dapat menghasilkan hubungan rantai pasok yang dinamis dan berdampak pada tingkat keuntungan yang dihasilkan (Huang dkk., 2003).

Peran rantai pasok dalam menghadapi persaingan yang semakin ketat dewasa ini sangat dibutuhkan terutama oleh para pelaku usaha mikro dan kecil pada sektor perikanan. Salah satu tantangan yang sering terjadi pada para pelaku usaha mikro dan kecil pada sektor perikanan adalah kemampuan mereka dalam menjaga tingkat efisiensi biaya dari rantai pasok yang ada (Tsolakis dkk. 2014). Hal ini terkait pelaku usaha dalam bidang perikanan yang memiliki kemampuan yang terbatas dalam mengontrol harga jual dari produk yang dihasilkan yang mana hal ini juga terkait dengan informasi yang dimiliki dan mampu untuk dikumpulkan. Para pelaku usaha perikanan secara umum hanya mampu mengontrol biaya produksi atau pada sisi hulu dan kurang memiliki kemampuan dalam mengontrol harga yang beredar di pasaran, dimana harga yang dijual di pasaran akan tergantung dengan biaya pemasaran dan biaya pengolahan (Landazuri-Tveteraas dkk., 2017) yang dikontrol oleh jaringan rantai pasok pada sisi hilir dari sektor perikanan seperti distributor.

Komoditas perikanan yang termasuk dalam sektor pertanian merupakan salah satu pangsa pasar terbesar di dunia, mengingat selain untuk konsumsi. Produk perikanan dapat digunakan sebagai produk antara untuk bahan produksi produk akhir sehingga secara umum produk perikanan dan pertanian secara umum memiliki potensi yang sangat besar. Meskipun demikian, secara umum produsen dari produk pada sektor ini adalah UMK (Usaha Mikro dan Kecil) sehingga hal ini juga yang menjadi kelemahan utama dari sektor perikanan dan pertanian secara umum,menyebabkanpelaku usaha dengan skala UMK menjadi semakin menurun (Jang dan Klien, 2011). Para pengusaha mikro dan kecil dalam sektor pertanian dan perikanan masih sangat sulit untuk bersaing dengan para pelaku usaha yang telah terstandarisasi secara manajemen dan proses produksi. Salah satu cara bagi para pengusaha mikro dan kecil pada sektor perikanan dan pertanian secara umum untuk dapat bertahan dan bersaing adalah dengan melakukan kerja sama dan membangun jaringan rantai pasok yang baik (Marsden dkk. 2000).

Kabupaten Maluku Tenggara yang merupakan wilayah kepulauan, pemerintah daerahnya telah menetapkan komoditas rumput laut sebagai produk unggulan daerah sejak tahun 2012. Meskipun demikian sejak tahun 2012 juga jumlah produksi rumput laut di wilayah ini menurun drastis yang diakibatkan oleh berbagai masalah antara lain harga, biaya produksi, tingkat permintaan dan serangan hama (Teniwut dan Kabalmay, 2014). Sebagian besar pelaku usaha budidaya rumput laut adalah pengusaha mikro yang melakukan usaha budidaya rumput laut dengan anggota keluarganya atau secara berkelompok dengan warga dalam satu desa. Dengan kondisi geografis dari Kabupaten Maluku Tenggara yang cenderung jauh dari pengguna produk rumput laut basah dan kering membuat kemampuan untuk berkoordinasi dengan pihak dalam rantai pasok pada sisi hilir secara individu menjadi semakin sulit dilakukan.

Rantai pasok budidaya rumput laut di Kabupaten Maluku Tenggara, dimulai supplier bahan baku dimana secara khusus di wilayah ini selain secara swadaya oleh petani, peran pemerintah daerah dalam rantai pasok budidaya rumput laut juga sebagai supplier bibit dan peralatan. Pemerintah daerah juga berperan dalam peningkatan kompetensi petani rumput laut yang 


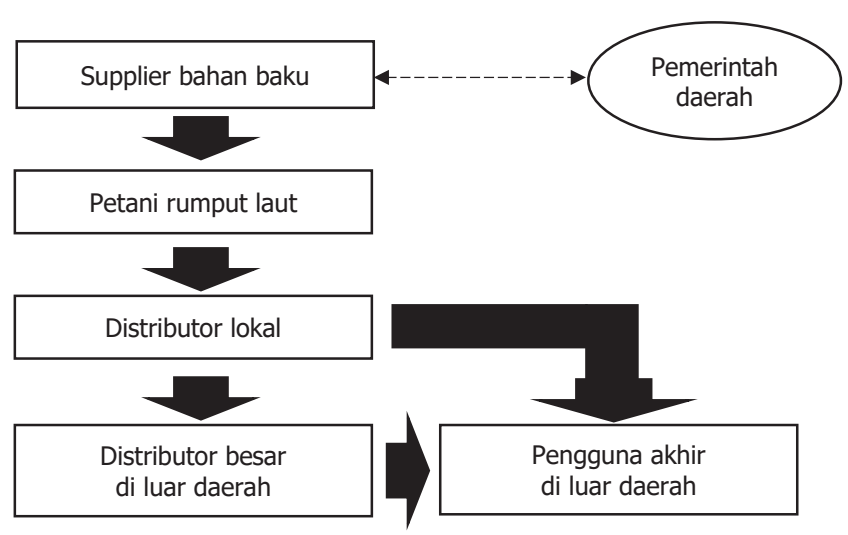

Gambar 1. Rantai pasok rumput laut Kabupaten Maluku Tenggara

ada dengan bekerja sama dengan perguruan tinggi dan lembaga penelitian. Tahapan selanjutnya adalah rumput laut yang dihasilkan oleh para petani, yang dijual kepada distributor besar dan beberapa distributor kecil untuk kemudian oleh distributor dijual ke Ambon yang merupakan salah satu distributor besar di Provinsi Maluku. Selain dijual ke distributor yang lebih besar di Ambon para distributor juga menjual hasil rumput laut yang diperoleh langsung ke Makasar dan/atau Surabaya, keputusan lokasi penjualan dipengaruhi oleh kualitas dan kuantitas dari hasil di wilayah Kabupaten Maluku Tenggara (Gambar 1). Di wilayah ini juga memiliki sebuah pabrik pengolahan tepung carrageenan, meskipun demikian hingga saat masih mengalami gangguan teknis sehingga belum dapat beroperasi dengan maksimal.

Hingga saat ini ketersediaan bibit unggul rumput laut yang berbasis kultur jaringan masih sangat jarang di wilayah ini. Selain beberapa pihak yang mampu menyediakan bibit unggul dengan jumlah yang sangat terbatas, satu-satunya pihak mampu menyediakan bibit unggul dalam jumlah besar adalah pemerintah daerah dan telah dilakukan, tetapi dalam pelaksanaannya masih sangat terbatas dan tidak merata. Kondisi ini berdampak pada tingkat ketahanan rumput laut pada serangan hama yang menyebabkan gagal panen.

Pada tingkat petani, selain faktor pengetahuan, modal dan kemampuan dalam menggunakan teknologi, faktor akases pasar di luar daerah menjadi salah satu kelamahan utama yang menyebabkan tingkat ketergantungan mereka pada distributor lokal. Kondisi ini membuat peran pemerintah menjadi sangat penting, dimana menurut Teniwut (2016) pemerintah baik pusat maupun daerah berperan penting dalam peningkatan kemampuan dari para petani budidaya, karena untuk sektor budidaya perikanan sangat membutuhkan pengetahuan yang mendalam (Diana dkk., 2013). Faktor rendahnya pengetahuan dalam proses pemilihan bibit yang disediakan supplier termasuk pembudidayaan jenis rumput laut yang memiliki nilai jual yang tinggi juga merupakan permasalahan tambahan yang dihadapi oleh jaringan rantai pasok rumput laut di Kabupaten Maluku Tenggara yang berimbas pada menurunnya jumlah produksi rumput laut di wilayah ini.

Pada tingkat distributor khususnya distributor lokal, terjadinya fluktuasi harga rumput laut dan kondisi harga kurang kompetitif akibat sedikitnya jumlah distributor lokal yang menyebabkan pengaruh mereka dalam mengontrol harga sangat tinggi karena kemampuan dalam modal dan informasi pasar yang dimiliki. Dengan kondisi dimana tidak terdapat pengguna akhir produk rumput laut basah maupun kering di wilayah ini maka kemampuan distributor dalam mengontrol harga semakin besar dikarenakan para distributor besar di wilayah ini memiliki informasi yang lebih pada jumlah permintaan rumput laut serta kemampuan modal dan akses pada pembeli dan pengguna akhir dari rumput laut yang ada di luar daerah. Hal ini menjadi salah satu penyebab terjadinya fluktuasi harga yang sangat signifikan dalam beberapa tahun terakhir, dimana berdasarkan hasil wawancara dengan warga dan data dari Pemda Kabupaten Maluku Tenggara bahwa pada tahun 2011 harga jual rumput laut kering mencapai Rp12.000,00/kg kemudian berubah terus menurun menjadi Rp8.000,00/kg pada tahun 2013 hingga pernah mencapai titik terendah sebesar Rp5.000,00/kg, kemudian naik lagi menjadi Rp6.000,00/kg - Rp7.000,00/kg pada tahun 2017.Selain peran distributor besar dalam terjadinya fluktuasi harga, kurangnya pengetahuan dasar maupun terapan dari para petani pada kegiatan budidaya rumput laut dari proses pemilihan bibit hingga proses panen juga merupakan beberapa faktor penyebab terjadinya fluktuasi harga (DKP Kabupaten Maluku Tenggara, 2016).

Pasar rumput laut yang sangat potensial dalam rangka peningkatan kinerja perekonomian rumah tangga pasa masyarakat pesisir di Kabupaten Maluku Tenggara yang akan menghadirkan efek multiplier pada perekonomian wilayah. Pada kenyataannya dilapangan saat ini, seperti yang telah diuraikan sebelumnya, beberapa poin permasalahan khususnya pada sisi hilir rantai pasok terutama jumlah permintaan pasar, lokasi pasar hingga harga yang beredar di luar wilayah Kabupaten Maluku Tenggara ini menyebabkan posisi petani rumput laut menjadi sangat inferior dibandingkan para distributor lokal akibat kurang simetrisnya informasi antar aktor dan kemampuan mengakses infomasi terkait pada rantai pasok rumput laut di wilayah ini.

Dengan demikian maka tujuan dari studi ini adalah melakukan identifikasi risiko-risiko yang muncul dalam rantai pasok budidaya rumput laut di Kabupaten 
Maluku Tenggara, menentukan risiko yang paling krusial untuk di atasi, menganalisis aktor atau pihak yang paling berperan dalam membantu mengatasi risiko rantai pasok rumput laut dan menentukan alternatif dan solusi yang efisien dan efektif untuk mengatasi risiko dan mengurangi adanya asimetris rantai pasok budidaya rumput laut di Kabupaten Maluku Tenggara.

\section{METODE PENELITIAN}

\section{Kerangka Pemikiran}

Beberapa hambatan yang dihadapi oleh petani budidaya perikanan adalah pengetahuan yang masih terbatas dan harga jual yang berfluktuasi (Akpabio dan Inyang 2007). Faktor lain yang juga signifikan berkontribusi pada masalah usaha budidaya rumpt laut adalah manajemen produksi rumput laut yang belum baik juga merupakan salah satu hambatan bagi peningkatan keuntungan dari petani rumput laut. Di Kabupaten Maluku Tenggara, petani rumput laut memiliki kemampuan tawar yang rendah dibandingkan aktor-aktor lain dalam rantai pasok rumput laut, karena informasi yang dimiliki sangat terbatas dan kemampuan untuk mengakses informasi juga terbatas karena kondisi geografis dan pengetahuan penggunaan teknologi informasi yang masih rendah. Distributor memiliki peran paling besar dalam mengontrol harga karena mereka memiliki informasi lebih terkait usaha rumput laut. Pada sisi lain pihak peran dari pemerintah daerah masih sangat terbatas dan kurang tanggap terhadap kondisi yang dihadapi oleh petani. Pemerintah daerah kurang mampu mengatasi permasalahan harga dan pengadaan bibit unggul serta cara penanganan hama yang selama ini dihadapi oleh petani rumput laut di wilayah ini (Teniwut dan Kabalmay, 2014).

Pada gambar 2 terlihat bahwa, tahapan pertama dalam penelitian ini dimulai dengan analisis kondisi operasional rantai pasok dilanjutkan dengan melakukan identifikasi risiko operasional rantai pasok dengan pendekatan SCOR (Supply Chain Operations Reference). Selanjutnya, penentuan risiko operasional rantai pasok yang menjadi prioritas untuk diatasi yang dilanjutkan dengan memilih aksi mitigasi yang efektif dan efisien

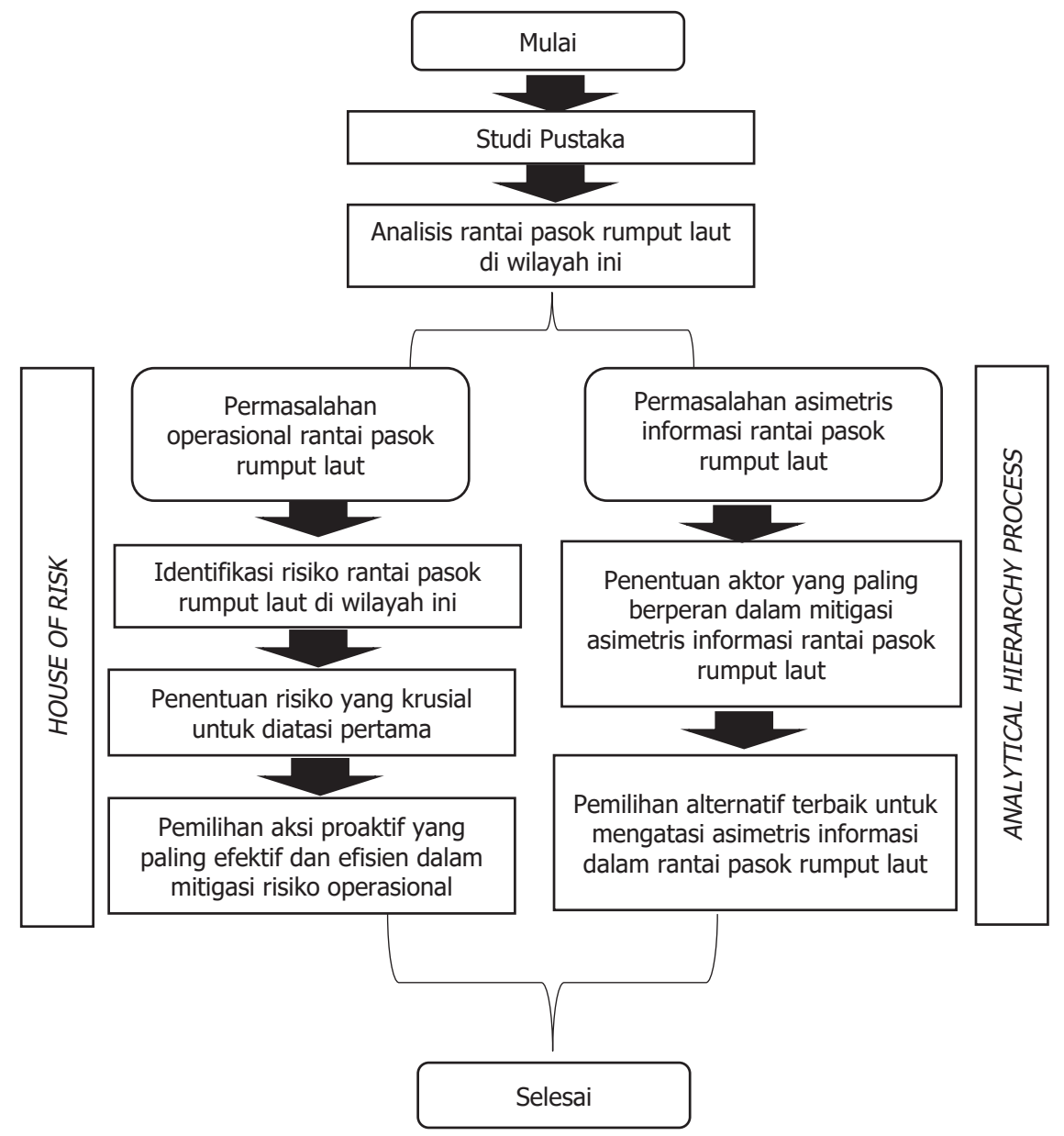

Gambar 2. Alur kerangka penelitian 
secara keuangan untuk dapat diimplementasikan dalam mengatasi risiko prioritas yang ada dengan menggunakan metode (HOR) (Pujawan dan Geraldin, 2009). Pada tahapan kedua, dimulai dengan mengidentifikasi kondisi aliran informasi pada rantai pasok rumput laut di wilayah ini, dilanjutkan dengan menentukan aktor yang paling berperan dalam membantu mengatasi adanya asimetris informasi pada rantai pasok rumput laut. Langkah final dari studi ini adalah memilih alternatif yang dapat mengatasi adanya asimetris rantai pasok di wilayah ini dengan menggunakan metodeAHP dengan pendekatan fuzzy Logic.

Pendekatan fuzzy AHP untuk mitigasi risiko pada rantai pasok telah banyak digunakan oleh para penelitian, seperti penelitian yang dilakukan oleh Septiani dan Djatna, (2015); Ganguly dan Guin (2013); Samvedi dkk., (2013); Taylan dkk. (2014); Ahmadi dkk. (2017). Meskipun demikian pengaplikasian FAHP masih terbatas pada risiko bidang manufaktor dan konstruksi sebagai obyek penelitian dan perhatian yang masih terbatas pada sektor-sektor yang secara langsung berhubungan dengan masyarakat UMKM seperti pertanian dan perikanan masih sangat terbatas. Hingga saat ini, kombinasi metode FAHP masih terbatas pada pendekatan MCDM yang umum seperti TOPSIS, ANP dan PROMETHEE sehingga penelitian ini menawarkan pendekatan yang masih sangat jarang dengan menggunakan (HOR) dan FAHP dalam menyelesaikan permasalahan rantai pasok pada sektor perikanan yang hingga saat ini masih sangat jarang penelitian rantai pasok pada sektor industri ini.

\section{Tata Laksana}

Untuk penyelesaian permasalahan risiko operasional rantai pasok rumput laut dengan metode (HOR) proses pengumpulan data dilakukan dengan depth interview dengan petani rumput laut, supplier dan distributor lokal di wilayah Kabupaten Maluku Tenggara yang mewakili praktisi, kemudian kepala sub bagian bidang budidaya perikana dinas Perikanan dan Kelautan Kabupaten Maluku Tenggara dan Sekretaris Badan Perencanaan Daerah Kabupaten Maluku Tenggara mewakili birokrat serta dosen dan peneliti bidang sosial ekonomi perikanan di Politeknik Perikanan Negeri Tual dan Teknik industri pertanian di IPB sebagai perwakilan dari akademisi mewakili akademisi. Dalam penanganan permasalahan asimetris rantai pasok rumput laut dengan pendekatan metode AHP dengan pendekatan Fuzzy Logic dimulai dengan pemilihan pakar yang dibagi menjadi tiga kategori yaitu praktisi, akademisi dan birokrat. Ketiga kategori pakar ini masing-masing berjumlah dua orang dan berasal dari wilayah Kabupaten Maluku Tenggara, Bogor dan Jakarta selain itu juga melakukan focus group discussion (FGD) dengan para petani rumput laut di wilayah ini. Untuk menghitung nilai dari House of Risk (HOR) dan fuzzy AHP dengan menggunakan aplikasi Microsoft Excel.

\section{Metode House of Risk (HOR)}

Kajian ini menggunakan metodeHouse of Risk (HOR) yang dikembangkan dan diperkenalkan pertama kali oleh Pujawan dan Gelardin (2009) yang merupakan integrasi dari Model Failure Modes and Effects Analysis (FMEA) dengan Model Quality Function Deployment (QFD). Metode ini terdiri dari dua bagian yaitu HOR1 dan HOR2.

\section{HOR1}

Tahapan dalam HOR1 terdiri dari empat tahap. Tahap pertama, mengidentifikasi risiko-risiko yang mungkin terjadi pada masing-masing proses bisnis. Hal ini bisa dilakukan dengan melakukan pemetaan proses rantai pasok seperti Plan, Source, Deliver, Make, dan Return (Model Supply Chain Operations Reference) lalu identifikasi "risiko apa yang bisa terjadi" pada masingmasing proses tersebut. Ei (risk events) menunjukkan risiko yang terjadi (Tabel 1). Tahapan kedua, memberikan penilaian dengan skala 1 sampai 5 pada severity akibat risiko yang terjadi. Si (severity) menunjukkan seberapa parahnya masing-masing risiko. Selanjutnya tahapan ketiga, melakukan identifikasi agen-agen risiko dan memberi penilaian mengenai kemungkinan terjadinya. Aj (risk agents) menunjukkan agen-agen risiko dan $\mathrm{Oj}$ (occurrence) menunjukkan kemungkinan terjadinya (Tabel 2). Tahap keempat, mengembangkan matriks keterkaitan (korelasi) antara masing-masing agen risiko dengan masing-masing risiko. Rij (relationship) \{0, 1, 3, 9\} dengan nilai 0 menunjukkan tidak ada korelasi (no correlation) dan nilai 1, 3, dan 9 menunjukkan korelasi rendah (low), sedang (moderate), dan tinggi (high).

Kemudian dilanjutkan dengan menghitung nilai ARP (Aggregate Risk Potential) dengan menggunakan Persamaan 1.

$$
A R P_{j}=O_{J} \sum_{i} S_{I} R_{I J}
$$

\section{HOR2}

HOR2 bertujuan untuk memilih aksi-aksi mitigasi dalam menangani risiko yang berpotensi timbul pada rantai pasok. Tahapan HOR2 dimulai dengan memiilih beberapa agen risiko dengan nilai tinggi (gunakan Diagram Pareto untuk ARPj) yang akan ditindaklanjuti pada HOR2. Agen-agen risiko yang terpilih diletakkan 
pada kolom sebelah kiri (apa saja agen risiko tersebut) dan pada kolom sebelah kanan (nilai ARPj). Selanjutnya, melakukan identifikasi aksi-aksi yang mungkin dilakukan untuk mencegah munculnya risiko. Aksi-aksi mitigasi tersebut letakkan pada baris atas HOR2 (Preventive ActionsPAk) (Tabel 3). Langkah berikutnya, menentukan korelasi antara masing-masing aksi pencegahan dan masing-masing agen risiko (Ejk). Ejk $\{0,1,3,9\}$ dengan nilai 0 menunjukkan tidak ada korelasi (no correlation) dan nilai 1, 3, dan 9 menunjukkan korelasi rendah, sedang, dan tinggi. Ejk juga menunjukkan tingkat keefektifan aksi mitigasi yang dilakukan dalam mengurangi kemungkinan munculnya agen risiko.

Langkah selanjutnya adalah menghitung Efektivitas Total (TEk) dari masing-masing aksi menggunakan Persamaan 2.

$$
T E_{k}=\sum_{j} A R P_{j} E j_{k} \quad \forall k
$$

Setelah mendapatkan nilai TEk dilanjutkan dengan memberi penilaian mengenai tingkat kesulitan dalam melakukan masing-masing aksi mitigasi (Difficulty Dk) menggunakan skala Likert yang menggambarkan kemampuan finansial atau sumber daya lain yang diperlukan selama aksi mitigasi dilakukan. Untuk kemudian dilanjutkan dengan menghitung Rasio Total Efektivitas (TEk) dengan Tingkat Kesulitan (Difficulty Dk) menggunakan Persamaan 3.

$$
E T D_{k}=\frac{T E_{k}}{D_{k}}
$$

Untuk kemudian menentukan peringkat prioritas dari masing-masing aksi $\left(R_{k}\right)$, peringkat pertama menunjukkan aksi dengan ETD tertinggi.

Tabel 2. Hasil agen risiko

\begin{tabular}{lcc}
\hline \multicolumn{1}{c}{ Risk agent } & Occurrence & Kode \\
\hline $\begin{array}{l}\text { Tingkat permintaan rumput laut yang } \\
\text { tidak stabil }\end{array}$ & 9 & A1 \\
$\begin{array}{l}\text { Rendahnya keakuratan bantuan dan } \\
\text { kemampuan dari Pemda }\end{array}$ & 7 & A2 \\
Ketersediaan bibit berkualitas & 5 & A3 \\
$\begin{array}{l}\text { Perubahan cuaca } \\
\text { IPTEK yang selalu berubah }\end{array}$ & 3 & A4 \\
$\begin{array}{l}\text { Tergantung pada distributor lokal } \\
\text { Konflik dengan sesama petani } \\
\text { Harga jual yang tidak kompetitif }\end{array}$ & 8 & A5 \\
$\begin{array}{l}\text { Rendahnya peran aktif LSM, lembaga } \\
\text { penelitian dan perguruan tinggi }\end{array}$ & 8 & A6 \\
$\begin{array}{l}\text { Lokasi geografis masing-masing desa } \\
\text { dengan pusat kota }\end{array}$ & 8 & A8 \\
\hline
\end{tabular}

\section{Metode fuzzy AHP}

Metode yang digunakan adalah fuzzy AHP untuk menentukan bobot alternatif dan memilih bobot alternatif yang paling besar dari input kuesioner penilaian para pakar. Langkah FAHP (Ayag dan Ozdemir, 2006) terdiri dari enam bagian. Langkah pertama adalah pembuatan struktur, Pada tahap ini struktur AHP pada

Tabel 1. Pengukuran kejadian risiko

\begin{tabular}{lllcc}
\hline SCOR & Sub proses & Risk event & Kode & S $_{i}$ \\
\hline Plan & Perencanaan Produksi & Tidak tersedianya informasi bibit unggul dari supplier & E1 & 3 \\
& & Informasi lokasi budidaya yang memenuhi standar & E2 & 2 \\
& Perkiraan Permintaan & Informasi perkiraan harga jual sepanjang tahun & E3 & 9 \\
& & Informasi jumlah permintaan dalam dan luar daerah & E4 & 9 \\
Source & Pengadaan & Bibit yang dibeli tidak sesuai secara kualitas dan jumlah & E5 & 6 \\
Make & Produksi & Rumput laut terserang hama & E6 & 9 \\
& & Perbandingan rumput laut kering dan basah tidak sesuai target & E7 & 7 \\
& & Terpaksa melakukan panen lebih cepat & E8 & 8 \\
Deliver & Pengiriman & Rumput laut rusak akibat proses terkena air tawar waktu & E9 & 9 \\
& & pengiriman & E10 & 4 \\
& & Jadwal pengiriman ke distributor yang terlambat & E11 & 4 \\
\multirow{2}{*}{ Return } & Pengembalian bibit ke & Keterlambatan dalam pengembalian bibit dari petani ke & E12 & 4 \\
\hline
\end{tabular}


Tabel 3. Opsi aksi mitigasi risiko rantai pasok

\begin{tabular}{|c|c|}
\hline Kode PA & Opsi aksi mitigasi \\
\hline PA1 & $\begin{array}{l}\text { Pemerintah daerah membangun perusahaan } \\
\text { (BUMD) pengolahan rumput laut }\end{array}$ \\
\hline PA2 & Membentuk komunitas petani rumput laut \\
\hline PA3 & $\begin{array}{l}\text { Membentuk pusat informasi yang komprehensif } \\
\text { hasil kerja sama Pemda, LSM, PT, dan lembaga } \\
\text { penelitian }\end{array}$ \\
\hline PA4 & $\begin{array}{l}\text { Pemanfaatan teknologi informasi untuk } \\
\text { komunikasi dan koordinasi }\end{array}$ \\
\hline PA5 & $\begin{array}{l}\text { Pemerintah daerah membuat kesepakatan } \\
\text { dengan supplier dan distributor mengenai } \\
\text { harga jual rumput laut (terkait subsidi) }\end{array}$ \\
\hline PA6 & $\begin{array}{l}\text { Pemda bekerja sama dengan LSM, PT, dan } \\
\text { lembaga penelitian membuat "hub rumput } \\
\text { laut" di masing-masing pulau besar di wilayah } \\
\text { Kepulauan Kei }\end{array}$ \\
\hline
\end{tabular}

mitigasi asimetris informasi rantai pasok terdiri dari lima level yaitugoal, kriteria, sub kriteria, aktor dan alternatif. Kemudian dilanjutkan dengan penilaian kriteria dan alternatif oleh pakar, dimana pakar melakukan penilaian tingkat kepentingan antar elemen berdasarkan definisi dan fungsi keanggotaan fuzzy pada Tabel 4. Setelah diperoleh penilaian pakar, maka dilakukan fuzzifikasi. Menurut Marimin dkk, (2013) fuzzifikasi pada metode fuzzy AHP adalah proses pengubahan nilai selang rating (berupa batas nilai) yang diberikan oleh penilai menjadi selang dalam bentuk bilangan fuzzy. Selang rating ini dibuat untuk memfasilitasi ketidakkonsistenan penilai. Fuzzifikasi dilakukan pada skala penilaian dan untuk menetapkan fungsi keanggotaan (membership function). Fuzzifikasi adalah proses pembentukan himpunan fuzzy dengan cara membentuk interval dari skala numerik untuk setiap atribut kepentingan. Setelah itu dilakukan defuzzifikasi yang merupakan proses pengubahan kembali output fuzzy ke output yang bernilai tunggal (crisp). Langkah selanjutnya adalah pembuatan matriks perbandingan berpasangan dan Perhitungan nilai bobot. Setiap nilai crisp elemen dimasukan kedalam matriks perbandingan berpasangan sesuai dengan kriteria pada struktur hierarki AHP. Kemudian dilakukan penggabungan pendapat pakar yang digabungkan dengan menggunakan geometric mean dengan Persamaan 4 (Marimin dan Maghfiroh, 2010).

$$
\bar{X}_{G}=\sqrt[n]{\prod_{i-1}^{n} X_{i}}
$$

dimana $\mathrm{n}$ adalah jumlah pakar dan adalah bobot dari masing-masing alternative
Langkah selanjutnya adalah menghitung Consistency Ratio (CR). Pada tahapan ini, pertama-tama lakukan kalkulasi Consistency Index (CI) (persamaan 5), kemudian dilanjutkan dengan membangun matriks perbandingan fuzzy berdasarkan representasi model TFN serta Menentukan Consistency Ratio $(C R<0,1)$ untuk menilai secara langsung konsistensi perbandingan berpasangan. Nilai CR dihitung dengan Persamaan 6.

$$
\begin{aligned}
& C I=\frac{\lambda \max -n}{n-1} \\
& \text { dimana }=\text { nilai maksimum dari eigen value berordo } \\
& \mathrm{n} . \\
& C R=\frac{C I}{R I} \\
& \text { dimana CI }=\text { Consistency Index dan } \mathrm{RI}=\text { Random } \\
& \text { Consistency Index. }
\end{aligned}
$$

Tabel 4. Definisi dan fungsi keanggotaan bilangan fuzzy

\begin{tabular}{clc}
\hline $\begin{array}{c}\text { Bilangan } \\
\text { Fuzzy }\end{array}$ & \multicolumn{1}{c}{ Skala linguistik } & $\begin{array}{c}\text { Fungsi } \\
\text { keanggotaan }\end{array}$ \\
\hline 1 & $\begin{array}{l}\text { Kedua faktor sama pentingnya } \\
\text { terhadap tujuan }\end{array}$ & $(1,1,3)$ \\
3 & $\begin{array}{l}\text { Satu faktor agak lebih penting } \\
\text { dari yang lain }\end{array}$ & $(1,3,5)$ \\
5 & $\begin{array}{l}\text { Satu faktor banyak lebih penting } \\
\text { dari yang lain }\end{array}$ & $(3,5,7)$ \\
7 & $\begin{array}{l}\text { Satu faktor sangat lebih penting } \\
\text { dari yang lain }\end{array}$ & $(5,7,9)$ \\
9 & $\begin{array}{l}\text { Satu faktor mutlak lebih penting } \\
\text { dari yang lain }\end{array}$ & $(7,9,11)$ \\
\hline
\end{tabular}

\section{HASIL DAN PEMBAHASAN}

\section{Penentuan Prioritas Sumber Risiko yang Diatasi Pertama}

Dari hasil perhitungan pada tahapan HOR1 (Tabel 5) dapat dilihat nilai Aggregate Risk Potential (ARP) dari masing-masing sumber risiko. Nilai tertinggi terdapat pada risiko dengan kode A6 (tergantung pada distributor lokal), diikuti secara berurutan oleh A8 (harga jual yang tidak kompetitif); A10 (lokasi geografis masing-masing desa dengan pusat kota); A9 (rendahnya peran aktif LSM, lembaga penelitian dan perguruan tinggi) dan A2 (rendahnya keakuratan bantuan dan kemampuan dari Pemerintah daerah). Pada gambar 3, dapat dilihat bahwa diagram pareto menunjukkan kelima risiko ini berkontribusi pada $70 \%$ risiko-risiko yang muncul pada rantai pasok rumput laut di Kabupaten Maluku Tenggara. Ketergantungan yang besar pada distributor 
lokal akibat tidak terdapatnya pengguna akhir produk rumput laut di wilayah ini merupakan faktor yang cukup krusial karena hal ini terkait juga dengan kekuatan petani rumput laut dalam daya tawar harga jual rumput laut. Distributor lokal mengontrol jumlah dan harga yang ingin dibeli dalam kondisi ini para petani yang sangat dirugikan. Berdasarkan hasil FGD yang dilakukan dengan petani rumput laut di wilayah ini, didapatkan alasan utama terjadi penurunan keinginan mereka untuk melakukan kegiatan budidaya rumput laut adalah karena harga yang sangat tidak kompetitif akibat ketergantungan pada distributor lokal. Kondisi geografis yang cenderung terisolasi lewat jalur darat maka dapat berdampak pada biaya pengiriman ke luar daerah. Dukungan dari pemerintah daerah, perguruan tinggi, lembaga penelitian dan LSM dirasa petani juga sangat kurang dan cenderung tidak tepat sasaran sesuai dengan kebutuhan petani, terutama pada ketersediaan bibit berkualitas dan serangan hama dan penyakit yang menyerang rumput laut.

\section{Aksi Mitigasi Risiko}

Dalam pendekatan (HOR) tahapan HOR2 ditujukan untuk memilih aksi yang secara finansial dan komitmen dapat dilaksanakan untuk mengatasi sumber risiko rantai pasok yang muncul (Pujawan dan Geraldin, 2009). Dari hasil penghitungan HOR2 pada Tabel 6 terlihat bahwa aksi mitigasi risiko yang efektif dan efisien secara biaya adalah PA2 dalam hal ini adalah membentuk komunitas petani rumput laut. Dibandingkan dengan solusi lain solusi ini secara komitmen dapat dilaksanakan dengan biaya yang tidak terlalu besar dibandingkan dengan opsi aksi mitigasi yang lain. Dengan adanya komunitas petani rumput laut maka para petani akan memiliki kekuatan dalam melakukan penawaran dengan distributor lokal pada harga.

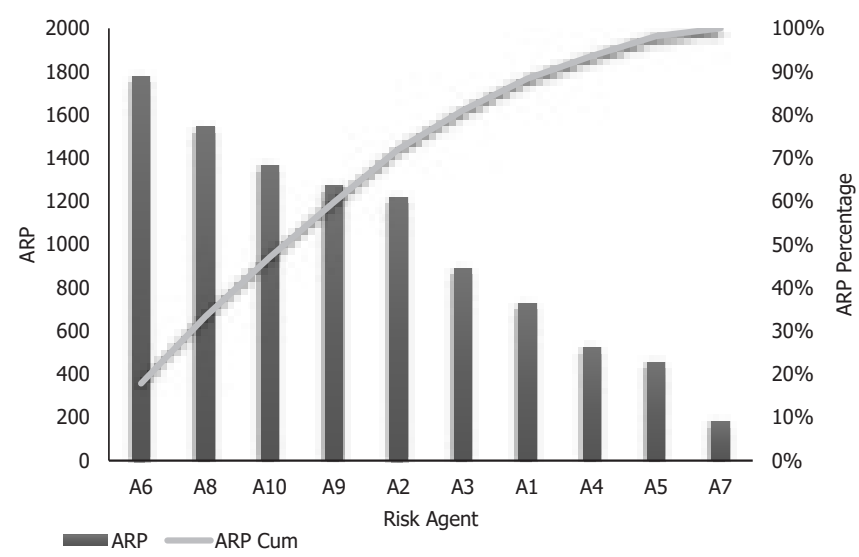

Gambar 3. Diagram Pareto

Tabel 5. Hasil penghitungan HOR1

\begin{tabular}{|c|c|c|c|c|c|c|c|c|c|c|c|c|c|}
\hline \multicolumn{14}{|c|}{ Risk agents } \\
\hline $\begin{array}{l}\text { Business } \\
\text { process }\end{array}$ & $\begin{array}{l}\text { Risk } \\
\text { Events }\end{array}$ & $\mathrm{A} 1$ & $\mathrm{~A} 2$ & $\mathrm{~A} 3$ & A4 & A5 & A6 & A7 & A8 & A9 & $\mathrm{A} 10$ & $\begin{array}{l}\text { Severity of } \\
\text { risk events }\end{array}$ & Value \\
\hline \multirow[t]{4}{*}{ Plan } & E1 & & 9 & 9 & & 6 & & & & 6 & 3 & $\mathrm{~S} 1$ & 3 \\
\hline & E2 & & 6 & & 6 & 6 & & 3 & & 6 & 6 & $\mathrm{~S} 2$ & 2 \\
\hline & E3 & & 6 & & & & 9 & 3 & 9 & 6 & 6 & S3 & 9 \\
\hline & E4 & 9 & 6 & & & & 9 & 3 & 9 & 6 & 6 & S4 & 9 \\
\hline Source & E5 & & & 9 & & 6 & & & & & 3 & S5 & 6 \\
\hline \multirow[t]{3}{*}{ Make } & E6 & & 3 & 6 & 6 & 3 & & & & & & S6 & 9 \\
\hline & E7 & & & 1 & & 3 & & & 1 & 3 & & S7 & 7 \\
\hline & E8 & & & & 9 & & 6 & & 3 & & & S8 & 8 \\
\hline \multirow[t]{3}{*}{ Deliver } & E9 & & & & & & & & & & 6 & S9 & 9 \\
\hline & E10 & & & & & & 3 & & & & 6 & S10 & 4 \\
\hline & E11 & & & & 6 & & & & & & 6 & $\mathrm{~S} 11$ & 4 \\
\hline Return & E12 & & & 9 & 3 & & & & & & 6 & $\mathrm{~S} 12$ & 4 \\
\hline Occurrence & & 9 & 7 & 5 & 3 & 4 & 8 & 3 & 8 & 8 & 5 & & \\
\hline$A R P$ & & 729 & 1218 & 890 & 522 & 456 & 1776 & 180 & 1544 & 1272 & 1365 & & \\
\hline \multicolumn{2}{|c|}{ Priority rank of agent } & 7 & 5 & 6 & 8 & 9 & 1 & 10 & 2 & 4 & 3 & & \\
\hline
\end{tabular}


Tabel 6. Hasil perhitungan HOR2

\begin{tabular}{|c|c|c|c|c|c|c|c|c|c|}
\hline & Risk agent & PA1 & PA2 & PA3 & PA4 & PA5 & PA6 & ARP & \\
\hline A6 & Tergantung pada distributor lokal & 9 & 3 & 3 & 3 & 9 & 3 & 1776 & ARP6 \\
\hline A8 & Harga jual yang tidak kompetitif & 9 & 9 & 3 & 3 & 9 & & 1544 & ARP8 \\
\hline A10 & $\begin{array}{l}\text { Lokasi geografis masing-masing desa } \\
\text { dengan pusat kota }\end{array}$ & & 9 & 9 & 9 & & 9 & 1365 & ARP10 \\
\hline A9 & $\begin{array}{l}\text { Rendahnya peran aktif LSM, Lembaga } \\
\text { Penelitian dan Perguruan Tinggi }\end{array}$ & & & 9 & 3 & & 9 & 1272 & ARP9 \\
\hline A2 & $\begin{array}{l}\text { Rendahnya keakuratan bantuan dan } \\
\text { kemampuan dari Pemda }\end{array}$ & 9 & 9 & 9 & 9 & 9 & 9 & 1218 & ARP2 \\
\hline TE & Total effectiveness of proactive action & 40842 & 42471 & 44655 & 37023 & 31107 & 40023 & & \\
\hline $\mathrm{D}$ & Difficulty performing action & 5 & 4 & 5 & 5 & 5 & 5 & & \\
\hline ETD & Effectiveness to difficulty ratio of action & 8,168 & 10,618 & 8,931 & 7,405 & 6,221 & 8,005 & & \\
\hline $\mathrm{R}$ & Rank of proactive action & 3 & 1 & 2 & 5 & 6 & 4 & & \\
\hline
\end{tabular}

Penentuan bobot metrik mitigasi asimetris informasi rantai pasok rumput laut di Kabupaten Maluku Tenggara dilakukan dengan pendekatan fuzzy AHP. Struktur hierarki pemilihan metrik terdiri dari lima level antara lain goal, kriteria, sub kriteria, aktor dan alternatif (Gambar 4).

\section{Pendorong Mitigasi Rantai Pasok}

Dari hasil perhitungan fuzzy AHP yang telah dilakukan menujukkan pada level kriteria ditemukan bahwa alasan diperlukannya mitigasi asimetris informasi rantai pasok rumput laut di Kabupaten Maluku Tenggara adalah peningkatan keuntungan petani rumput laut kemudian diikuti secara berurutan oleh mengurangi fluktuasi harga dan meningkatkan kepercayaan dalam rantai pasok. Hasil ini sangat dimengerti karena rumput laut memberikan efek multiplier ekonomi yang signifikan dalam peningkatan kesejahteraan masyarakat pesisir, dan kondisi ini memaksa terjadinya perpindahan lapangan kerja dari sektor perikanan lain ke budidaya

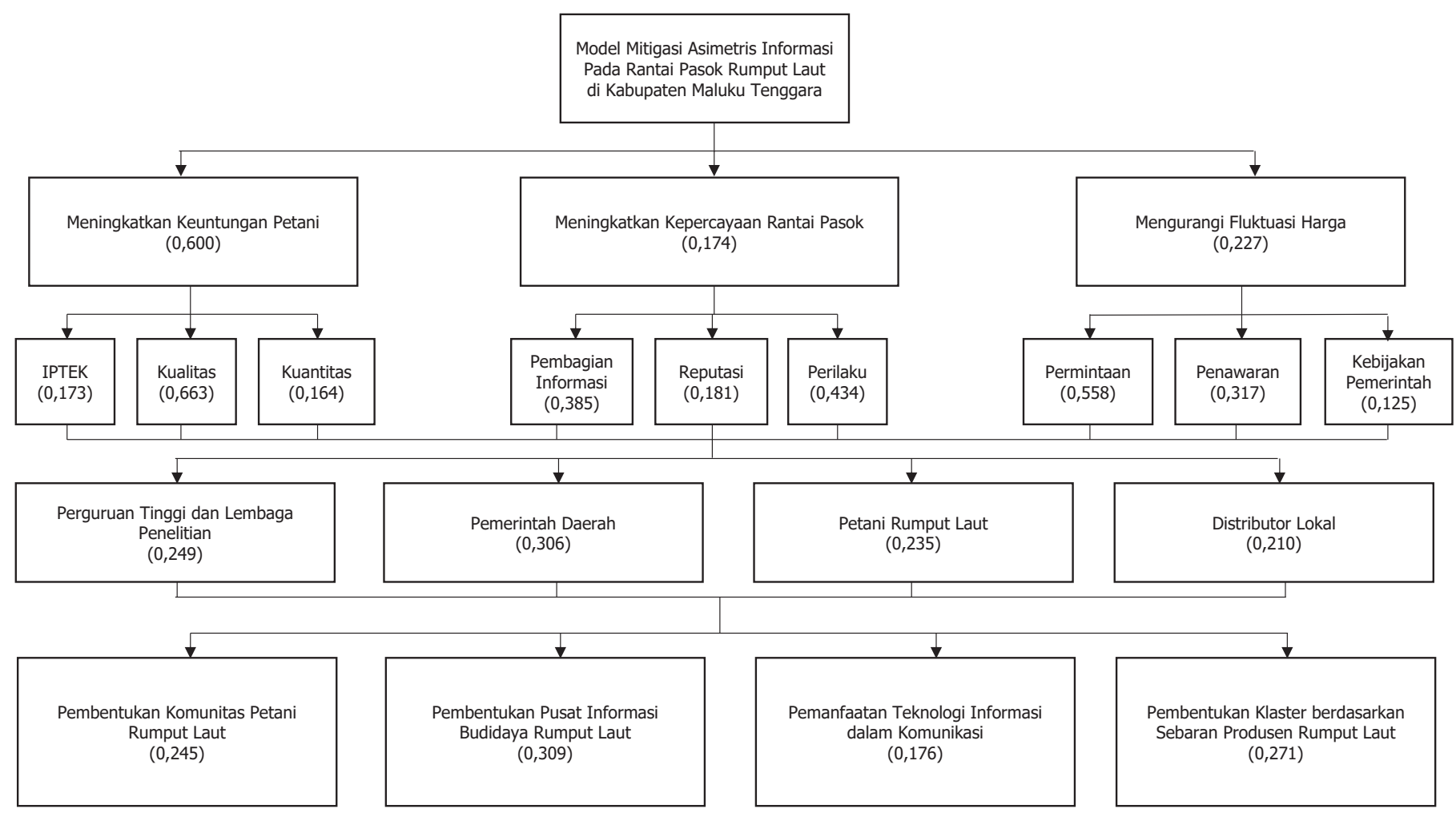

Gambar 4. Struktur hierarki mitigasi asimetris rantai pasok rumput laut di Kabupaten Maluku Tenggara 
rumput laut di Indonesia (Crawford, 2002 dan Sievanen dkk., 2005). Untuk dapat meningkatkan keuntungan petani maka diperlukan proses pemilihan yang baik pada pemasok hingga distributor (Suharjito dkk., 2011).

Selain pemilihan pemasok hingga distributor, transmisi harga jual yang baik juga berpengaruh pada keuntungan petani. Di Kabupaten Maluku Tenggara, transmisi harga jual rumput laut kurang berjalan dengan baik dari distributor ke para petani rumput laut. Transmisi harga yang tidak berjalan dengan baik sering terjadi pada sektor perikanan baik produk perikanan maupun olahan (Gordon and Hussain, 2015; Sapkota, dkk. 2015), hal ini dikarenakan kompleksitas dari aktor-aktor dan hubungannya dalam rantai pasok dalam sektor perikanan (Matopoulos dkk., 2007) yang didorong oleh usaha untuk memanfaatkan sumber daya informasi lebih yang dimiliki oleh salah satu pihak dalam rantai pasok dalam hal ini adalah distributor rumput laut di Kabupaten Maluku Tenggara.Distributor menganggap informasi sebagai asset dan memperolehnya dengan mengeluarkan biaya sehingga hal ini menyulitkan terjadinya perpindahan informasi dari distributor ke pihak lain dalam rantai pasok (Huang dan Yang, 2016; Lei dkk., 2015).

Untuk sub kriteria yang paling penting untuk diperhatikan dalam rangka peningkatan keuntungan optimal oleh para petani adalah menjaga dan meningkatkan kualitas hasil rumput laut yang dihasilkan, Bixler and Porse (2011) mengemukakan bahwa keuntungan para petani rumput laut dipengaruhi oleh konsistensi dari kualitas rumput laut yang dijual yang diakibatkan oleh pengetahuan dan teknologi yang terbatas, selain itu faktor lain yang juga mempengaruhi adalah ketersediaan kualitas bibit yang tersedia sangat terbatas. Kondisi ini juga sesuai dengan situasi di lapangan dimana terbatasnya informasi yang dimiliki oleh petani jenis dan kualitas bibit yang disediakan oleh supplier membuat hasil rumput laut yang diproduksi tidak konsisten sepanjang musim yang berdampak pada keuntungan petani. Kurangnya informasi mengenai teknik budidaya rumput laut yang baik, pengetahuan pada waktu panen sesuai juga berpengaruh pada keuntungan yang diperoleh petani. Kondisi ini menyebabkan rumput laut yang dipanen tidak sesuai standar yang berdampak pada kualitas rumput laut yang dijual yang akhirnya berpengaruh pada penurunan harga jual dan berdampak pada tingkat keuntungan petani.

\section{Aktor dalam Mitigasi Asimetris Rantai Pasok}

Penyebab awal terjadinya penurunan jumlah produksi rumput laut di Kabupaten Maluku Tenggara adalah serangan hama ice-ice pada tahun 2011.
Kondisi ini berpengaruh pada kualitas rumput laut yang dihasilkan dan berpengaruh pada harga jual. Selain serangan hama, harga jual yang cenderung menurun sejak tahun 2012 juga berpengaruh pada keinginan petani untuk tetap melakukan budidaya rumput laut. Hal ini membuat peran pemerintah daerah yang memiliki sumber daya dan akses besar menjadi signifikan. Kondisi ini sejalan dengan hasil penghitungan fuzzy AHP menunjukkan bahwa peran pemerintah daerah sangat dibutuhkan dalam pengadaan peralatan mengingat sebagian besar petani rumput laut adalah masyarakat pesisir yang memiliki kemampuan modal yang cukup terbatas.

Selain pemerintah daerah, peran perguruan tinggi dan lembaga penelitian juga cukup penting dimana perlunya kerja sama antara perguruan tinggi dan lembaga penelitian di wilayah ini dengan pemerintah daerah dalam rangka mengatasi permasalahan yang dihadapi oleh petani baik terkait dengan proses produksi, paska panen hingga akses ke modal, seperti yang dilakukan di Negara lain seperti Mexico dengan program PET (Temporary Employment Programmes) dalam rangka membantu petani rumput laut di Negara itu (Robledo dkk. 2013). Perguruan tinggi dan lembaga penelitian juga diharapkan dapat memberikan masukan terkait pasar rumput laut diluar daerah termasuk metode untuk menjaga kualitas produk rumput laut yang dihasilkan.

\section{Alternatif Mitigasi Asimetris Rantai Pasok Rumput Laut}

Alternatif terbaik dalam mengatasi asimetris rantai pasok rumput laut di Kabupaten Maluku Tenggara adalah pembentukan pusat informasi budidaya rumput laut sebesar 0,309, selanjutnya diikuti oleh pembentukan kluster berdasarkan sebaran produsen rumput laut sebesar 0,271. Urutan alternatif secara berurutan selanjutnya adalah pembentukan komunitas petani rumput laut sebesar 0,245 diikuti dengan pemanfaatan teknologi infomasi dalam komunikasi sebesar 0,176.

Dari penghitungan fuzzy AHP yang telah dilakukan alternatif terbaik untuk saat ini dalam rangka mengatasi asimetris rantai pasok rumput laut di Kabupaten Maluku Tenggara maka pembentukan pusat informasi budidaya rumput laut menjadi sebuah keharusan. Berdasarkan hasil diskusi dengan para petani dan survei lapangan yang telah dilakukan menunjukkan dengan kondisi geografis wilayah ini, maka sangat dibutuhkan setidaknya dua pusat informasi yang terletak pada dua pulau besar di Kabupaten Maluku Tenggara. Dengan demikian maka akan memudahkan koordinasi terkait dengan informasi pada jenis dan lokasi pembelian bibit rumput laut yang sesuai dan memiliki kualitas yang 
baik serta adanya bargaining pada jumlah dan harga jual rumput laut di wilayah ini ke distributor (Lyon, 2003). Dari hasil penghitungan Fuzzy AHP yang telah dilakukan, menemukan bahwa membangun klusterkluster rumput laut berdasarkan sebaran-sebaran desa produsen rumput laut di wilayah ini juga menjadi salah satu solusi dalam mitigasi asimetris informasi rantai pasok rumput laut di wilayah ini. Dengan adanya kluster rumput laut juga memungkinkan peluang untuk terjadinya koordinasi horizontal untuk dapat mengurangi ketergantungan pada satu aliran rantai pasok sehingga dapat meningkatkan efisiensi dan keuntungan (Boute dan Lambrecht, 2007), selain itu juga untuk semakin menguatkan koordinasi vertikal antar petani rumput laut sehingga akan mengurangi risiko dalam rantai pasok (Mau dan Mau 2009).

\section{KESIMPULAN}

Dari hasil penelitian yang telah dilakukan, tingkat keuntungan yang meningkat merupakan alasan utama yang menjadi pendorong perlu dilakukannya mitigasi rantai pasok rumput laut di Kab Maluku Tenggara. Faktor yang paling penting untuk diperhatikan adalah kualitas produk rumput laut yang dijual, selanjutnya aktor atau pihak yang paling berperan dalam mengatasi kondisi ini adalah pemerintah daerah yang diikuti oleh perguruan tinggi dan lembaga penelitian. Hasil kajian ini juga menunjukkan bahwa peran pemerintah daerah berperan penting dalam menyediakan informasi pada bibit dan pasar rumput laut di luar daerah. Untuk dapat mengurangi adanya risiko rantai pasok dan adanya asimetris informasi rantai pasok rumput laut di wilayah ini, perlu dilakukan pembentukan pusat informasi rumput laut yang merupakan wadah bagi petani untuk saling bertukar informasi kaitannya dengan penanganan hama, perolehan bibit berkualitas dan tingkat permintaan serta harga jual. Bagi penelitian selanjutnya agar lebih fokus pada studi yang lebih spesifik pada kondisi sosial ekonomi dan budaya dari masyarakat pesisir termasuk melakukan kajian yang lebih mendalam pada keterkaitan antara lokasi geografis antara Kabupaten Maluku Tenggara yang merupakan wilayah kepulauan dengan wilayah lain di Provinsi Maluku dan Indonesia dan antar desa-desa di Kabupaten Maluku Tenggara yang juga tersebar pada pulau-pulau kecil dengan rantai pasok rumput laut.

\section{UCAPAN TERIMA KASIH}

Terima kasih disampaikan kepada Direktorat Riset dan Pengabdian Masyarkat (DRPM) Kementerian Riset
Teknologi dan Pendidikan Tinggi Republik Indonesia yang telah membiayai penelitian ini melalui Hibah Kompetitif Nasional pada Skim Penelitian Kerja Sama Antar Perguruan Tinggi (PKPT) Tahun 2017-2018 No: 025/E3/2017, 06 Januari 2017.

\section{KONFLIK KEPENTINGAN}

Penulis menyatakan tidak ada konflik kepentingan dengan pihak-pihak yang terkait dalam penelitian ini.

\section{DAFTAR PUSTAKA}

Ahmadi, M., Behzadian, K., Ardeshir, A., \& Kapelan, Z. (2017). Comprehensive risk management using fuzzy FMEA and MCDA techniques in highway construction projects. Journal of Civil Engineering and Management. https:// doi.org/10.3846/13923730.2015.1068847

Akpabio, I. A., \& Inyang, E. B. (2007). Major constraints affecting aquaculture development in Akwa Ibom State, Nigeria. African Journal of Aquatic Science. https://doi. org/10.2989/AJAS.2007.32.1.7.144

Ayağ, Z., \& Özdemir, R. G. (2006). A fuzzy AHP approach to evaluating machine tool alternatives. Journal of Intelligent Manufacturing. https://doi.org/10.1007/ s10845-005-6635-1

Bixler, H. J., \& Porse, H. (2011). A decade of change in the seaweed hydrocolloids industry. Journal of Applied Phycology. https://doi.org/10.1007/s10811-010-9529-3

Boute, R., Manage-, T., Lambrecht, M., \& Management, I. (2007). Altruistic Behavior in Supply Chain Management. Review of Business and Economic Literature, LII(3), 499-516.

Crawford, B. (2002). Seaweed Farming: An Alternative Livelihood for Small-Scale Fishers? In Coastal Resources Center.

Diana, J. S., Egna, H. S., Chopin, T., Peterson, M. S., Cao, L., Pomeroy, R., Verdegem, M., Slack, W. T., BondadReantaso, M. G., \& Cabello, F. (2013). Responsible aquaculture in 2050: Valuing local conditions and human innovations will be key to success. BioScience. https:// doi.org/10.1525/bio.2013.63.4.5

DKP Kabupaten Maluku Tenggara. (2016). Laporan Statistik Perikanan Budidaya Kabupaten Maluku Tenggara Tahun 2015. Dinas Kelautan dan Perikanan Kabupaten Maluku Tenggara.

Doukidis, G. I., Matopoulos, A., Vlachopoulou, M., Manthou, V., \& Manos, B. (2007). A conceptual framework for supply chain collaboration: Empirical evidence from the agri-food industry. Supply Chain Management: An International Journal. https://doi.org/10.1108/13598540710742491 
Ganguly, K. K., \& Guin, K. K. (2013). A fuzzy AHP approach for inbound supply risk assessment. Benchmarking. https:// doi.org/10.1108/14635771311299524

Gordon, D. V., \& Hussain, S. (2015). Price Determination and Demand Flexibilities in the Ex-Vessel Market for Tuna in the Republic of Maldives. Aquaculture Economics and Management. https://doi.org/10.1080/13657305.2015. 994234

Gunasekaran, A., Williams, H. J., \& McGaughey, R. E. (2005). Performance measurement and costing system in new enterprise. Technovation. https://doi.org/10.1016/ S0166-4972(03)00176-7

Huang, G. Q., Lau, J. S. K., \& Mak, K. L. (2003). The impacts of sharing production information on supply chain dynamics: A review of the literature. In International Journal of Production Research. https://doi. org/10.1080/0020754031000069625

Huang, S., \& Yang, J. (2016). Information acquisition and transparency in a supply chain with asymmetric production cost information. International Journal of Production Economics. https://doi.org/10.1016/j. ijpe.2016.10.005

Jang, W., \& Klein, C. M. (2011). Supply chain models for small agricultural enterprises. Annals of Operations Research. https://doi.org/10.1007/s10479-009-0521-8

Landazuri-Tveteraas, U., Asche, F., Gordon, D. V., \& Tveteraas, S. L. (2018). Farmed fish to supermarket: Testing for price leadership and price transmission in the salmon supply chain. Aquaculture Economics and Management. https://doi.org/10.1080/13657305.2017.1284943

Lei, Q., Chen, J., Wei, X., \& Lu, S. (2015). Supply chain coordination under asymmetric production cost information and inventory inaccuracy. International Journal of Production Economics. https://doi. org/10.1016/j.ijpe.2015.09.015

Lyon, F. (2003). Community groups and livelihoods in remote rural areas of Ghana: How small-scale farmers sustain collective action. Community Development Journal. https://doi.org/10.1093/cdj/38.4.323

Marsden, T., Banks, J., \& Bristow, G. (2000). Food supply chain approaches: Exploring their role in rural development. Sociologia Ruralis. https://doi.org/10.1111/14679523.00158

Marimin, M. N., Suharjito, H. S., Utama, D. N., Astuti, R., \& Martini, S. (2013). Teknik dan analisis pengambilan keputusan fuzzy dalam manajemen rantai pasok. Bogor: IPB Press.

Marimin dan Maghfiroh N. (2010). Aplikasi Teknik Pengambilan Keputusan Dalam Manajemen Rantai Pasok. Bogor: IPB Press.

Mau, N., \& Mau, M. (2009). Securing global food distribution networks. In International Series in Operations Research and Management Science. https://doi.org/10.1007/9780-387-79934-6_20

Pujawan, I. N., \& Geraldin, L. H. (2009). House of risk: A model for proactive supply chain risk management. Business Process Management Journal, 15(6), 953-967. https:// doi.org/10.1108/14637150911003801

Robledo, D., Gasca-Leyva, E. \& Fraga, J. (2013). Social and economic dimensions of carrageenan seaweed farming in Mexico. In D. Valderrama, J. Cai, N. Hishamunda \& N. Ridler, eds. Social and economic dimensions of carrageenan seaweed farming, pp. 185- 204. Fisheries and Aquaculture Technical Paper No. 580. Rome, FAO. $204 \mathrm{pp}$.

Samvedi, A., Jain, V., \& Chan, F. T. S. (2013). Quantifying risks in a supply chain through integration of fuzzy AHP and fuzzy TOPSIS. International Journal of Production Research. https://doi.org/10.1080/00207543.2012.741 330

Sapkota, P., Dey, M. M., Alam, M. F., \& Singh, K. (2015). Price Transmission Relationships along the Seafood Value Chain in Bangladesh: Aquaculture and Capture Fisheries. Aquaculture Economics and Management. https://doi.or $\mathrm{g} / 10.1080 / 13657305.2015 .994237$

Septiani, W., \& Djatna, T. (2015). Rancangan Model Performansi Risiko Rantai Pasok Agroindustri Susu dengan Menggunakan Pendekatan Logika Fuzzy. Agritech.

Sievanen, L., Crawford, B., Pollnac, R., \& Lowe, C. (2005). Weeding through assumptions of livelihood approaches in ICM: Seaweed farming in the Philippines and Indonesia. Ocean and Coastal Management. https://doi. org/10.1016/j.ocecoaman.2005.04.015

Suharjito., Machfud., Haryanto, B., \& Marimin. (2011). Pemodelan optimasi mitigasi risiko rantai pasok produk/ komoditas Jagung. Agritech, 31(3), 215-227. https:// doi.org/10.22146/agritech.9747

Taylan, O., Bafail, A. O., Abdulaal, R. M. S., \& Kabli, M. R. (2014). Construction projects selection and risk assessment by fuzzy AHP and fuzzy TOPSIS methodologies. Applied Soft Computing Journal. https://doi.org/10.1016/j. asoc.2014.01.003

Teniwut, W. A., Kabalmay, J. (2014). Studi Empiris : EValuasi usaha budidaya rumput laut di kabupaten maluku tenggara. Prosiding Seminar IImiah Tahunan Ke-2 Tahun 2014 "Perikanan dan Pembangunan," 55-60.

Teniwut, W. A. (2016). For sustainable revenue of fisheries sector in small islands: Evidence of Maluku, Indonesia. AACL Bioflux. https://doi.org/10.5281/zenodo.245507

Tsolakis, N. K., Keramydas, C. A., Toka, A. K., Aidonis, D. A., \& Iakovou, E. T. (2014). Agrifood supply chain management: A comprehensive hierarchical decisionmaking framework and a critical taxonomy. In Biosystems Engineering. https://doi.org/10.1016/j. biosystemseng.2013.10.014 